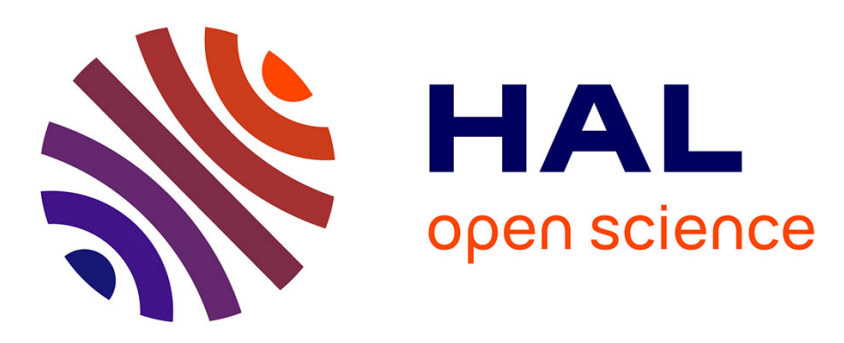

\title{
Facile synthesis of monodisperse Cu3SbSe4 nanoparticles and thermoelectric performance of Cu3SbSe4 nanoparticle-based materials
}

Yimin Wu, Xvsheng Qiao, Xianping Fan, Xianghua Zhang, Shuo Cui, Jun Wan

\section{To cite this version:}

Yimin Wu, Xvsheng Qiao, Xianping Fan, Xianghua Zhang, Shuo Cui, et al.. Facile synthesis of monodisperse $\mathrm{Cu} 3 \mathrm{SbSe} 4$ nanoparticles and thermoelectric performance of $\mathrm{Cu} 3 \mathrm{SbSe} 4$ nanoparticlebased materials. Journal of Nanoparticle Research, 2015, 17 (7), In press. 10.1007/s11051-015-30942. hal-01174904

\section{HAL Id: hal-01174904 https://hal-univ-rennes1.archives-ouvertes.fr/hal-01174904}

Submitted on 16 Sep 2015

HAL is a multi-disciplinary open access archive for the deposit and dissemination of scientific research documents, whether they are published or not. The documents may come from teaching and research institutions in France or abroad, or from public or private research centers.
L'archive ouverte pluridisciplinaire HAL, est destinée au dépôt et à la diffusion de documents scientifiques de niveau recherche, publiés ou non, émanant des établissements d'enseignement et de recherche français ou étrangers, des laboratoires publics ou privés. 


\title{
Facile synthesis of monodisperse $\mathrm{Cu}_{3} \mathrm{SbSe}_{4}$ nanoparticles and thermoelectric performance of $\mathrm{Cu}_{3} \mathrm{SbSe}_{4}$ nanoparticles-based \\ materials
}

Yimin $\mathrm{Wu}^{1}$, Xvsheng Qiao ${ }^{1}$, Xianping Fan ${ }^{1, *}$, Xianghua Zhang ${ }^{2}$, Shuo Cui ${ }^{1}$, Jun Wan ${ }^{1}$

${ }^{1}$ State Key Laboratory of Silicon Materials, Department of Materials Science and

Engineering, Zhejiang University, Hangzhou 310027, P.R. China

${ }^{2}$ Laboratory of Glasses and Ceramics, Institute of Chemistry, CNRS-Université de

Rennes I, campus de Beaulieu, 35042 Rennes cedex, France

*Corresponding author. Tel: 0086-571-87951234; Fax: 0086-571-87951234; E-mail:

fanxp@ zju.edu.cn

\begin{abstract}
Large-scale $\mathrm{Cu}_{3} \mathrm{SbSe}_{4}$ and $\mathrm{Cu}_{3} \mathrm{Sb}_{0.98} \mathrm{Sn}_{0.02} \mathrm{Se}_{4}$ nanoparticles with a narrow size distribution were synthesized through a rapid-injection route. Those nanoparticles showed a monodisperse and quasi-spherical morphology. The $\mathrm{Cu}_{3} \mathrm{SbSe}_{4}$ and $\mathrm{Cu}_{3} \mathrm{Sb}_{0.98} \mathrm{Sn}_{0.02} \mathrm{Se}_{4}$ nanoparticles-based bulk materials were then prepared by hot-pressing sinter of the nanoparticles, and their thermoelectric performances were systematically studied. Due to the reduced lattice thermal conductivity from enhanced phonon scattering at the grain interfaces of the bulk materials, the maximum ZT value of the $\mathrm{Cu}_{3} \mathrm{Sb}_{0.98} \mathrm{Sn}_{0.02} \mathrm{Se}_{4}$ bulk materials reached 0.50 at $575 \mathrm{~K}$.
\end{abstract}

Keywords: $\mathrm{Cu}_{3} \mathrm{SbSe}_{4}$ nanoparticles; thermoelectric; rapid-injection route 


\section{Introduction}

During the past few decades, continuous efforts have been devoted to improving the performance of thermoelectric (TE) materials for their applications in cooling and power generation (Hicks and Dresselhaus 1993; O'Dwyer et al. 2006; Pei et al. 2011; Poudel et al. 2008; Shakouri 2011; Yang et al. 2008). Copper-based multinary semiconductors with zinc blende related crystal structures have recently emerged as some of the best performing p-type thermoelectric materials (Shi et al. 2010; Shi et al. 2009; Skoug et al. 2011; Skoug et al. 2012; Zou et al. 2014). One example is ternary p-type $\mathrm{Cu}_{3} \mathrm{SbSe}_{4}$ semiconductor. Its unique crystal structures increase the phonon-phonon interactions, resulting in a quite low phonon conductivity (Skoug et al. 2012; Zou et al. 2014). Thus the ternary p-type $\mathrm{Cu}_{3} \mathrm{SbSe}_{4}$ semiconductor has been considered to be an important kind of thermoelectric materials and has caused wide public concern in the past few decades (Do et al. 2012; Yang et al. 2011).

It is well known that the TE performance is characterized by the dimensionless figure of merit:

$$
\mathrm{ZT}=\mathrm{S}^{2} \sigma \mathrm{T} / \kappa
$$

where $S$ is the Seebeck coefficient, $\sigma$ is electrical conductivity, $\kappa$ is thermal conductivity and $\mathrm{T}$ is absolute temperature, respectively. Therefore, higher electrical conductivity and lower thermal conductivity will significantly improve TE performance of thermoelectric materials. Thus the TE performances of the thermoelectric materials are largely dependent on the preparation method which can 
greatly change their microstructure (Biswas et al. 2012). To date, almost all the $\mathrm{Cu}_{3} \mathrm{SbSe}_{4}$-based materials were fabricated by solid state reactions (Fan et al. 2013; Li et al. 2013; Liu et al. 2009; Skoug et al. 2011; Skoug et al. 2012; Zou et al. 2014). The $\mathrm{Cu}_{3} \mathrm{SbSe}_{4}$ nanoparticles might be used as the starting materials of $\mathrm{Cu}_{3} \mathrm{SbSe}_{4}$-based thermoelectric materials because they could result in grain refinement in consolidated bulk, generating a large quantity of phonon scattering at grain boundaries to reduce the lattice thermal conductivity. Li et al. (Li et al. 2013) have firstly reported a co-precipitation synthesis of $\mathrm{Sn}$ and/or $\mathrm{S}$ doped $\mathrm{Cu}_{3} \mathrm{SbSe}_{4}$ powders with 300-500 nm diameters which were composed by plenty of agglomerated nanospheres with their diameters around $50 \mathrm{~nm}$. However, as far as we know there have been no reports on synthesis of the monodisperse $\mathrm{Cu}_{3} \mathrm{SbSe}_{4}$ nanoparticles and the TE performances of the $\mathrm{Cu}_{3} \mathrm{SbSe}_{4}$-based thermoelectric materials which were prepared by the monodisperse $\mathrm{Cu}_{3} \mathrm{SbSe}_{4}$ nanoparticles. In this paper, we demonstrate a facile rapid-injection route for the large-scale synthesis of the monodisperse $\mathrm{Cu}_{3} \mathrm{SbSe}_{4}$ and $\mathrm{Cu}_{3} \mathrm{Sb}_{0.98} \mathrm{Sn}_{0.02} \mathrm{Se}_{4}$ nanoparticles. The TE properties of the $\mathrm{Cu}_{3} \mathrm{SbSe}_{4}$ and $\mathrm{Cu}_{3} \mathrm{Sb}_{0.98} \mathrm{Sn}_{0.02} \mathrm{Se}_{4}$ bulk materials which were prepared by hot-pressed sinter of the nanoparticles were described.

\section{Experimental}

The $\mathrm{Cu}_{3} \mathrm{SbSe}_{4}$ and $\mathrm{Cu}_{3} \mathrm{Sb}_{0.98} \mathrm{Sn}_{0.02} \mathrm{Se}_{4}$ nanoparticles were synthesized by reacting $\mathrm{CuCl}_{2} \cdot 2 \mathrm{H}_{2} \mathrm{O}, \mathrm{SbCl}_{3}$, and $\mathrm{SnCl}_{2} \cdot 2 \mathrm{H}_{2} \mathrm{O}$ with an excess of selenium precursor in the presence of hexadecylamine (HDA). In a typical procedure, $1.5 \mathrm{mmol} \mathrm{CuCl}_{2} \cdot 2 \mathrm{H}_{2} \mathrm{O}$ 
(99.99\%, aladdin), $0.5 \mathrm{mmol} \mathrm{SbCl}_{3}\left(99.99 \%\right.$, aladdin) and $\mathrm{SnCl}_{2} \cdot 2 \mathrm{H}_{2} \mathrm{O}(99.99 \%$, aladdin), 15 mmol HDA (90\%, aladdin) and $30 \mathrm{ml}$ octadecene (ODE, 90\%, Aldrich) were introduced into a three-neck flask and heated to $200^{\circ} \mathrm{C}$ under the protection of argon until all precursors were dissolved and the solution became transparent and light yellow. Afterward, the solution was cooled to $180^{\circ} \mathrm{C}$ and maintained under argon for 0.5 hour to remove oxygen, water and other relatively volatile impurity organic solvents which may exist in commercial solvent. Then $12 \mathrm{ml}$ ODE-Se (0.8 M) solution was injected through a syringe. The excess selenium leaded to the instantaneous formation of nuclei of cationic selenide, guarantees the uniformity of grain size and hinders the growth behavior during the grain nucleation. And it could also insure a complete reaction. The mixture was maintained at $180^{\circ} \mathrm{C}$ for different time from $0 \mathrm{~min}$ up to $60 \mathrm{~min}$ and then rapidly cooled down to room temperature in air. Along with the increase of reacting time, the suspension mixtures appeared a color change from a light orange to an eventually deep green color which qualitatively indicated the acquisition of $\mathrm{Cu}_{3} \mathrm{SbSe}_{4}$ nanoparticles. To remove the weakly bound HDA, $9 \mathrm{ml}$ of oleic acid (OA, 90\%, Aldrich) was added to the mixture during the cooling step at about $70^{\circ} \mathrm{C}$ ( $\mathrm{Li}$ et al. 2013). And finally the nanoparticles were isolated and purified using chloroform and isopropanol to complete the standard solvent/nonsolvent precipitation/redispersion procedure. To characterize the TE properties of the compacted bulk materials, the $\mathrm{Cu}_{3} \mathrm{SbSe}_{4}$ and $\mathrm{Cu}_{3} \mathrm{Sb}_{0.98} \mathrm{Sn}_{0.02} \mathrm{Se}_{4}$ nanoparticles were dried under vacuum at $40^{\circ} \mathrm{C}$ for nearly 12 hours and then hot-pressed sintered into dense pellets under a pressure of $80 \mathrm{MPa}$ at $350^{\circ} \mathrm{C}$ for 1 hour. 
The densities values of the $\mathrm{Cu}_{3} \mathrm{SbSe}_{4}$ and $\mathrm{Cu}_{3} \mathrm{Sb}_{0.98} \mathrm{Sn}_{0.02} \mathrm{Se}_{4}$ pellets are $4.84 \mathrm{~g} / \mathrm{cm}^{3}$ and $4.92 \mathrm{~g} / \mathrm{cm}^{3}$ respectively.

Transmission electron microscopy (TEM) images were obtained from a Philips CM200 field emission transmission electron microscope. High resolution transmission electron microscopy (HRTEM) images and selected area electron diffraction (SAED) patterns were obtained from a FEI Tecnai G2 F20 field emission transmission electron microscope. X-ray diffraction (XRD) analysis was carried out on a PANalytical B.V Empyrean 200895 X-ray diffractometer. The electrical conductivity and the Seebeck coefficient were measured on a computer-aided apparatus using a four-probe method and differential voltage/temperature technique, respectively. The thermal diffusivity and the specific heat capacity were measured on a laser flash apparatus (Netzsch LFA 457). The thermal conductivity $\kappa$ was calculated from the relationship $\kappa=\rho D C_{p}$, where $D$ is the thermal diffusivity, $C_{p}$ the specific heat capacity and $\rho$ the density of the sample estimated by an ordinary dimensional and weight measurement procedure.

\section{Results and discussion}

Fig.1(a) shows the XRD patterns of the $\mathrm{Cu}_{3} \mathrm{SbSe}_{4}$ nanoparticles which were synthesized at $180^{\circ} \mathrm{C}$ for $0 \mathrm{~min}, 10 \mathrm{~min}, 30 \mathrm{~min}$ and $60 \mathrm{~min}$, which exhibits prominent peaks well accordant with JCPDS standard card (JCPDS 85-0003) of the tetragonal-phase $\mathrm{Cu}_{3} \mathrm{SbSe}_{4}$ without a second phase. It is obvious that the rapid injection which involves the injection of a "cold" (room temperature) solution of 
precursor molecules into hot liquid (de Mello Donega et al. 2005) is an effective method for synthesis of pure phase $\mathrm{Cu}_{3} \mathrm{SbSe}_{4}$ nanoparticles. The Scherrer formula was used to calculate the mean crystallite size according to the full width at half maximum (FWHM) of XRD peaks. The size of the $\mathrm{Cu}_{3} \mathrm{SbSe}_{4}$ nanoparticles which were synthesized at $180^{\circ} \mathrm{C}$ for 10 min could be calculated to be about $35 \mathrm{~nm}$. Fig.1(b) shows the XRD patterns of the $\mathrm{Cu}_{3} \mathrm{SbSe}_{4}$ and $\mathrm{Cu}_{3} \mathrm{Sb}_{0.98} \mathrm{Sn}_{0.02} \mathrm{Se}_{4}$ nanoparticles which were synthesized at $180^{\circ} \mathrm{C}$ for $10 \mathrm{~min}$. Similar XRD patterns could be observed, which indicated that the Sn doping has no significantly influence on the crystalline phase of the $\mathrm{Cu}_{3} \mathrm{SbSe}_{4}$ nanoparticles. Fig. 2 shows the TEM images of the $\mathrm{Cu}_{3} \mathrm{SbSe}_{4}$ nanoparticles which were synthesized at $180^{\circ} \mathrm{C}$ for $0 \mathrm{~min}, 10 \mathrm{~min}, 30 \mathrm{~min}$ and $60 \mathrm{~min}$. It is clear that the $\mathrm{Cu}_{3} \mathrm{SbSe}_{4}$ nanoparticles synthesized at $180^{\circ} \mathrm{C}$ for 10 min exhibited a quasi-spherical morphology with a narrow size distribution around $35 \mathrm{~nm}$. This observed size is in good agreement with the size calculated with the Scherrer equation. With increase of reaction time, the mean nanoparticle size increases gradually. HRTEM analysis of a randomly selected nanoparticle (inset of fig.2(b)) confirmed its highly crystalline nature with a tetragonal phase lattice fringes associated with (112)

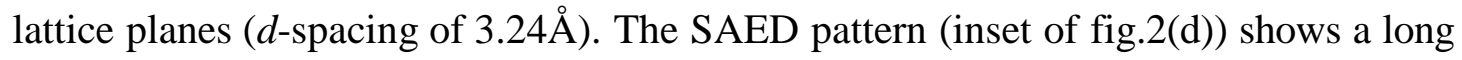
regularly ordered diffraction spots which could be indexed to the (112), (105) and (217) planes of the tetragonal structure of the permingeatite whose lattice spacing were $3.24 \AA, 2.09 \AA$ and $1.34 \AA$, respectively. Fig.3(a) shows the TEM image of the $\mathrm{Cu}_{3} \mathrm{Sb}_{0.98} \mathrm{Sn}_{0.02} \mathrm{Se}_{4}$ nanoparticles which were synthesized at $180^{\circ} \mathrm{C}$ for $10 \mathrm{~min}$. Similar to $\mathrm{Cu}_{3} \mathrm{SbSe}_{4}$ nanoparticles, the $\mathrm{Cu}_{3} \mathrm{Sb}_{0.98} \mathrm{Sn}_{0.02} \mathrm{Se}_{4}$ nanoparticles also show a 
quasi-spherical morphology and a narrow size distribution around $35 \mathrm{~nm}$, which is also consistent with Scherrer-calculated size. Therefore the Sn doping has no significant influence on the morphology and size of the nanoparticles.

Indeed, the nanoparticles synthesis could be resolved into an initial nucleating stage and a subsequent self-growth stage whose cluster growth occurred by monomer deposition, which depletes the metastable phase of monomer and causes stable clusters to grow regardless of their size. In the second stage, an Ostwald ripening process plays key roles in the formation of the ending size. This ripening model is based on the Kelvin equation, which gives the relationship for the ratio of interfacial energy to thermal energy. The smaller clusters are less stable than larger ones and therefore larger clusters grow at the expense of smaller ones (Madras and McCoy 2001). On this basis, the bulk TE materials were prepared by hot-pressed sinter of the $\mathrm{Cu}_{3} \mathrm{SbSe}_{4}$ and $\mathrm{Cu}_{3} \mathrm{Sb}_{0.98} \mathrm{Sn}_{0.02} \mathrm{Se}_{4}$ nanoparticles which were synthesized at $180^{\circ} \mathrm{C}$ for $10 \mathrm{~min}$ due to their narrow size distribution at around $35 \mathrm{~nm}$. From the SEM image (Fig.3(b)), however, it can be found that the grain size of samples which were hot-pressed sintered at $350^{\circ} \mathrm{C}$ for 1 hour showed an obvious growth from nanoscale to microscale. The average grain size was about $1 \mu \mathrm{m}$. High surface energy of nanoparticles and extra energy provided by hot pressing might be main driving forces of this grain growth.

Fig.4 shows the TE behaviors of the $\mathrm{Cu}_{3} \mathrm{SbSe}_{4}$ and $\mathrm{Cu}_{3} \mathrm{Sb}_{0.98} \mathrm{Sn}_{0.02} \mathrm{Se}_{4}$ bulk materials which were prepared by hot-pressed sinter of the $\mathrm{Cu}_{3} \mathrm{SbSe}_{4}$ and $\mathrm{Cu}_{3} \mathrm{Sb}_{0.98} \mathrm{Sn}_{0.02} \mathrm{Se}_{4}$ nanoparticle under a pressure of $80 \mathrm{MPa}$ at $350^{\circ} \mathrm{C}$ for 1 hour. The 
electrical conductivity $(\sigma)$ of the $\mathrm{Cu}_{3} \mathrm{Sb}_{0.98} \mathrm{Sn}_{0.02} \mathrm{Se}_{4}$ bulk materials was greatly enhanced in comparison with $\mathrm{Cu}_{3} \mathrm{SbSe}_{4}$ bulk materials, which is consistent with a previous reports ( $\mathrm{Li}$ et al. 2014; Nolas et al. 2000). This could be explained by the introduction of acceptor energy level in the band gap by Sn doping, which give rise to the increase of hole concentration ( $\mathrm{Li}$ et al. 2013). Indeed, the acceptor centers in the $\mathrm{Cu}_{3} \mathrm{SbSe}_{4}$ were reported to relate to the $\mathrm{Cu}$ and/or Sb defects (Li et al. 2013; Wei et al. 2014). Due to the radius difference between $\mathrm{Sn}^{4+}(0.69 \AA)$ and $\mathrm{Sb}^{5+}(0.61 \AA)$, the substitution of Sb by $\mathrm{Sn}$ would produce lattice distortion and point defects such as vacancies of $\mathrm{Cu}$ and/or Sb. From fig.4(a) it can also be found that the electrical conductivity of the undoped $\mathrm{Cu}_{3} \mathrm{SbSe}_{4}$ bulk materials increases slightly with temperature, indicating a non-degenerate semiconductor-like behavior ( $\mathrm{Li}$ et al. 2013). In contrast, the temperature dependence of the electrical conductivity for the $\mathrm{Cu}_{3} \mathrm{Sb}_{0.98} \mathrm{Sn}_{0.02} \mathrm{Se}_{4}$ bulk materials decreased gradually with an increase of temperature, which exhibited metallic-like or degenerate semiconductor behavior (Li et al. 2014).

Fig.4(b) shows the dependence of the Seebeck coefficient (S) on temperature for the $\mathrm{Cu}_{3} \mathrm{SbSe}_{4}$ and $\mathrm{Cu}_{3} \mathrm{Sb}_{0.98} \mathrm{Sn}_{0.02} \mathrm{Se}_{4}$ bulk materials in the temperature range of $300-600 \mathrm{~K}$. The positive values revealed that they were p-type materials with holes as their main charge carriers. The Seebeck coefficient of the $\mathrm{Cu}_{3} \mathrm{SbSe}_{4}$ initially decreased with the increase of the temperature and then increased with further increase in temperature, leaving a minimum located around at $425 \mathrm{~K}$. For $\mathrm{Cu}_{3} \mathrm{Sb}_{0.98} \mathrm{Sn}_{0.02} \mathrm{Se}_{4}$, a similar $\mathrm{S}$ variation with the temperature could be also observed, but the fluctuation range is much narrower. Moreover, the introduction of Sn resulted 
in the decrease of the Seebeck coefficient. Many researches have shown that the Seebeck coefficient and the electrical conductivity were not independent because they have a close relationship with carrier concentration (GODART 2009; Lenoir et al. 2010; Mateeva et al. 1998; Zhu et al. 2004). Hence, a compromise between large Seebeck coefficient and electrical conductivity of the TE materials should be chosen to maximize the power factor, which reveals the ability of one thermoelectric material producing useful electrical power. Fig.4(c) shows the dependence of the power factor $\left(\mathrm{PF}=\mathrm{S}^{2} \sigma\right.$ ) on temperature for the $\mathrm{Cu}_{3} \mathrm{SbSe}_{4}$ and $\mathrm{Cu}_{3} \mathrm{Sb}_{0.98} \mathrm{Sn}_{0.02} \mathrm{Se}_{4}$ bulk materials. The $\mathrm{Cu}_{3} \mathrm{Sb}_{0.98} \mathrm{Sn}_{0.02} \mathrm{Se}_{4}$ reached the highest PF value $\left(1.31 \times 10^{-3} \mathrm{Wm}^{-1} \mathrm{~K}^{-2}\right)$ at $300 \mathrm{~K}$.

To calculate the figure of merit (ZT) of the $\mathrm{Cu}_{3} \mathrm{SbSe}_{4}$ and $\mathrm{Cu}_{3} \mathrm{Sb}_{0.98} \mathrm{Sn}_{0.02} \mathrm{Se}_{4}$ bulk materials, the thermal conductivities $(\kappa)$ were calculated by multiplying thermal diffusivity, specific heat capacity and density. Fig.4(d) shows the dependence of thermal conductivities ( $\kappa$ ) on temperature for the $\mathrm{Cu}_{3} \mathrm{SbSe}_{4}$ and $\mathrm{Cu}_{3} \mathrm{Sb}_{0.98} \mathrm{Sn}_{0.02} \mathrm{Se}_{4}$ bulk materials. The thermal conductivities $(\kappa)$ between $300 \mathrm{~K}$ and $570 \mathrm{~K}$ fluctuated in the range of $0.91 \sim 1.15 \mathrm{Wm}^{-1} \mathrm{~K}^{-1}$ for the $\mathrm{Cu}_{3} \mathrm{SbSe}_{4}$ and $1.10 \sim 1.25 \mathrm{Wm}^{-1} \mathrm{~K}^{-1}$ for the $\mathrm{Cu}_{3} \mathrm{Sb}_{0.98} \mathrm{Sn}_{0.02} \mathrm{Se}_{4}$. The lowest $\kappa$ value, as low as $0.91 \mathrm{Wm}^{-1} \mathrm{~K}^{-1}$, was observed for $\mathrm{Cu}_{3} \mathrm{SbSe}_{4}$ at $425 \mathrm{~K}$. This extremely low thermal conductivity could be attributed to the reduction of the lattice thermal conductivity by increased grain boundary scattering when the $\mathrm{Cu}_{3} \mathrm{SbSe}_{4}$ bulk materials were prepared by hot-pressed sinter of the $\mathrm{Cu}_{3} \mathrm{SbSe}_{4}$ nanoparticles.

Fig.5 shows the dependence of the figure of merit on temperature for the $\mathrm{Cu}_{3} \mathrm{SbSe}_{4}$ and the $\mathrm{Cu}_{3} \mathrm{Sb}_{0.98} \mathrm{Sn}_{0.02} \mathrm{Se}_{4}$ bulk materials. The $\mathrm{ZT}$ values increased basically 
with increasing temperature. It is obvious that the introduction of $\mathrm{Sn}$ improved significantly the ZT values. The maximum $\mathrm{ZT}$ value reached 0.50 at $575 \mathrm{~K}$ for $\mathrm{Cu}_{3} \mathrm{Sb}_{0.98} \mathrm{Sn}_{0.02} \mathrm{Se}_{4}$ bulk materials, which is larger than that the sample prepared by the solid state reactions (Skoug et al. 2012). Evidently, this improvement in the thermoelectric properties originated mainly from its higher power factor and lower thermal conductivity (Yang et al. 2011; Zou et al. 2014). Note that further improvement in the sintering technology, such as the substitution of hot pressing by spark plasma sintering, may thwart grain growth and promote densification. This provides the possibility to improve electrical conductivity and decrease thermal conductivity simultaneously, which will further enhance the ZT values of the $\mathrm{Cu}_{3} \mathrm{SbSe}_{4}$ nanoparticles-based TE materials.

\section{Conclusions}

We have demonstrated a rapid-injection route to synthesize the $\mathrm{Cu}_{3} \mathrm{SbSe}_{4}$ and $\mathrm{Cu}_{3} \mathrm{Sb}_{0.98} \mathrm{Sn}_{0.02} \mathrm{Se}_{4}$ nanoparticles which showed a monodisperse and quasi-spherical morphology. The mean nanoparticle size could be adjusted by controlling the reaction time. Those nanoparticles with a smaller size and controlled shape could be used as the starting powders for preparing bulk thermoelectric materials, which resulted in increased grain boundary scattering to reduce the lattice thermal conductivity. The maximum ZT value reached 0.50 at $575 \mathrm{~K}$ for the $\mathrm{Cu}_{3} \mathrm{Sb}_{0.98} \mathrm{Sn}_{0.02} \mathrm{Se}_{4}$ bulk materials which were prepared by hot-pressed sinter of the $\mathrm{Cu}_{3} \mathrm{Sb}_{0.98} \mathrm{Sn}_{0.02} \mathrm{Se}_{4}$ nanoparticles. 


\section{Acknowledgements:}

The authors gratefully acknowledge support for this research from the Program for Innovative Research Team in University of Ministry of Education of China (IRT13R54).

\section{References}

Biswas K, He J, Blum ID, Wu CI, Hogan TP, Seidman DN, Dravid VP and Kanatzidis MG (2012) High-performance bulk thermoelectrics with all-scale hierarchical architectures. Nature:414-8. doi: 10.1038/nature11439

de Mello Donega C, Liljeroth P and Vanmaekelbergh D (2005) Physicochemical evaluation of the hot-injection method, a synthesis route for monodisperse nanocrystals. Small:1152-62. doi: 10.1002/smll.200500239

Do D, Ozolins V, Mahanti SD, Lee MS, Zhang Y and Wolverton C (2012) Physics of bandgap formation in $\mathrm{Cu}-\mathrm{Sb}$-Se based novel thermoelectrics: the role of $\mathrm{Sb}$ valency and $\mathrm{Cu}$ d levels. Journal of Physics Condensed Matter : an Institute of Physics journal:415502. doi: 10.1088/0953-8984/24/41/415502

Fan J, Liu HL, Shi XY, Bai SQ, Shi X and Chen LD (2013) Investigation of thermoelectric properties of $\mathrm{Cu}_{2} \mathrm{Ga}_{\mathrm{x}} \mathrm{Sn}_{(1-\mathrm{x})} \mathrm{Se}_{3}$ diamond-like compounds by hot pressing and spark plasma sintering. Acta Materialia:4297-4304. doi: DOI 10.1016/j.actamat.2013.04.003

GODART C (2009) Materiaux a Effets Thermoelectriques. Éditions techniques de l'ingénieur 
Hicks LD and Dresselhaus MS (1993) Thermoelectric figure of merit of a one-dimensional conductor. Physical Review B, Condensed Matter:16631-16634. doi: 10.1103/Phys Rev B.47.16631

Lenoir B, Michenaud J-P and Dauscher A (2010) Thermoelectricite: des Principes aux Applications. Éditions techniques de l'ingénieur

Li D, Li R, Qin X-Y, Zhang J, Song C-J, Wang L and Xin H-X (2013) Co-precipitation synthesis of $\mathrm{Sn}$ and/or $\mathrm{S}$ doped nanostructured $\mathrm{Cu}_{3} \mathrm{Sb}_{1-\mathrm{x}} \mathrm{Sn}_{\mathrm{x}} \mathrm{Se}_{4-\mathrm{y}} \mathrm{S}_{\mathrm{y}}$ with a high thermoelectric performance. CrystEngComm:7166. doi: 10.1039/c3ce40956b

Li D, Li R, Qin XY, Song CJ, Xin HX, Wang L, Zhang J, Guo GL, Zou TH, Liu YF and Zhu XG (2014) Co-precipitation synthesis of nanostructured $\mathrm{Cu}_{3} \mathrm{SbSe}_{4}$ and its Sn-doped sample with high thermoelectric performance. Dalton Trans:1888-96. doi: 10.1039/c3dt52447g

Li W, Zamani R, Ibanez M, Cadavid D, Shavel A, Morante JR, Arbiol J and Cabot A (2013) Metal ions to control the morphology of semiconductor nanoparticles: copper selenide nanocubes. Journal of Amercial Chemistry Society:4664-7. doi: $10.1021 / \mathrm{ja} 400472 \mathrm{~m}$

Li XY, Li D, Xin HX, Zhang J, Song CJ and Qin XY (2013) Effects of bismuth doping on the thermoelectric properties of $\mathrm{Cu}_{3} \mathrm{SbSe}_{4}$ at moderate temperatures. Journal of Alloys and Compounds:105-108. doi: 10.1016/j.jallcom.2013.01.131

Liu ML, Chen IW, Huang FQ and Chen LD (2009) Improved Thermoelectric 
Properties of $\mathrm{Cu}$ - Doped Quaternary Chalcogenides of $\mathrm{Cu}_{2} \mathrm{CdSnSe}_{4}$. Advanced Materials:3808-3812

Madras G and McCoy BJ (2001) Distribution kinetics theory of Ostwald ripening. Journal of Chemical Physics:6699-6706. doi: Doi 10.1063/1.1403687

Mateeva N, Niculescu H, Schlenoff J and Testardi L (1998) Correlation of Seebeck coefficient and electric conductivity in polyaniline and polypyrrole. Journal of Applied Physics:3111-3117

Nolas GS, Takizawa H, Endo T, Sellinschegg H and Johnson DC (2000) Thermoelectric properties of Sn-filled skutterudites. Applied Physics Letters:52. doi: 10.1063/1.126874

O’Dwyer MF, Humphrey TE and Linke H (2006) Concept study for a high-efficiency nanowire based thermoelectric. Nanotechnology:S338-S343. doi: $10.1088 / 0957-4484 / 17 / 11 / \mathrm{s} 18$

Pei Y, Shi X, LaLonde A, Wang H, Chen L and Snyder GJ (2011) Convergence of electronic bands for high performance bulk thermoelectrics. Nature:66-9. doi: 10.1038/nature09996

Poudel B, Hao Q, Ma Y, Lan YC, Minnich A, Yu B, Yan XA, Wang DZ, Muto A, Vashaee D, Chen XY, Liu JM, Dresselhaus MS, Chen G and Ren ZF (2008) High-thermoelectric performance of nanostructured bismuth antimony telluride bulk alloys. Science:634-638. doi: 10.1126/science.1156446

Shakouri A (2011) Recent Developments in Semiconductor Thermoelectric Physics and Materials. In: DR Clarke and P Fratzl (eds) Annual Review of Materials 
Research, Vol 41. Annual Reviews, Palo Alto, pp 399-431

Shi X, Xi L, Fan J, Zhang $\mathrm{W}$ and Chen L (2010) Cu-Se Bond Network and Thermoelectric Compounds with Complex Diamondlike Structure. Chemistry of Materials:6029-6031. doi: 10.1021/cm101589c

Shi XY, Huang FQ, Liu ML and Chen LD (2009) Thermoelectric properties of tetrahedrally bonded wide-gap stannite compounds $\mathrm{Cu}_{2} \mathrm{ZnSn}_{1-\mathrm{x}} \mathrm{In}_{\mathrm{x}} \mathrm{Se}_{4}$. Applied Physics Letters:122103. doi: 10.1063/1.3103604

Skoug EJ, Cain JD and Morelli DT (2011) High thermoelectric figure of merit in the $\mathrm{Cu}_{3} \mathrm{SbSe}_{4}-\mathrm{Cu}_{3} \mathrm{SbS}_{4}$ solid solution. Applied Physics Letters. doi: $10.1063 / 1.3605246$

Skoug EJ, Cain JD and Morelli DT (2012) Improved Thermoelectric Performance in Cu-Based Ternary Chalcogenides Using S for Se Substitution. Journal of Electronic Materials:1232-1236. doi: 10.1007/s11664-012-1969-х

Wei T-R, Wang H, Gibbs ZM, Wu C-F, Snyder GJ and Li J-F (2014) Thermoelectric properties of $\mathrm{Sn}$-doped p-type $\mathrm{Cu}_{3} \mathrm{SbSe}_{4}$ : a compound with large effective mass and small band gap. Journal of Materials Chemistry A:13527-13533

Yang CY, Huang FQ, Wu LM and Xu K (2011) New stannite-like p-type thermoelectric material $\mathrm{Cu}_{3} \mathrm{SbSe}_{4}$. Journal of Physics D-Applied Physics. doi: $10.1088 / 0022-3727 / 44 / 29 / 295404$

Yang SH, Zhu TJ, Sun T, He J, Zhang SN and Zhao XB (2008) Nanostructures in high-performance $(\mathrm{GeTe})_{\mathrm{x}}\left(\mathrm{AgSbTe}_{2}\right)_{100-\mathrm{x}}$ thermoelectric materials. Nanotechnology:245707. doi: 10.1088/0957-4484/19/24/245707 
Zhu P, Imai Y, Isoda Y, Shinohara Y, Jia X, Ren G and Zou G (2004) Electrical transport and thermoelectric properties of PbTe prepared by HPHT. Materials Transactions:3102-3105

Zou TH, Qin XY, Li D, Li LL, Sun GL, Wang QQ, Zhang J, Xin HX, Liu YF and Song CJ (2014) Enhanced thermoelectric performance of $\beta-\mathrm{Zn}_{4} \mathrm{Sb}_{3}$ based composites incorporated with large proportion of nanophase $\mathrm{Cu}_{3} \mathrm{SbSe}_{4}$. Journal of Alloys and Compounds:568-572. doi: 10.1016/j.jallcom.2013.11.049 


\section{Captions of figures}
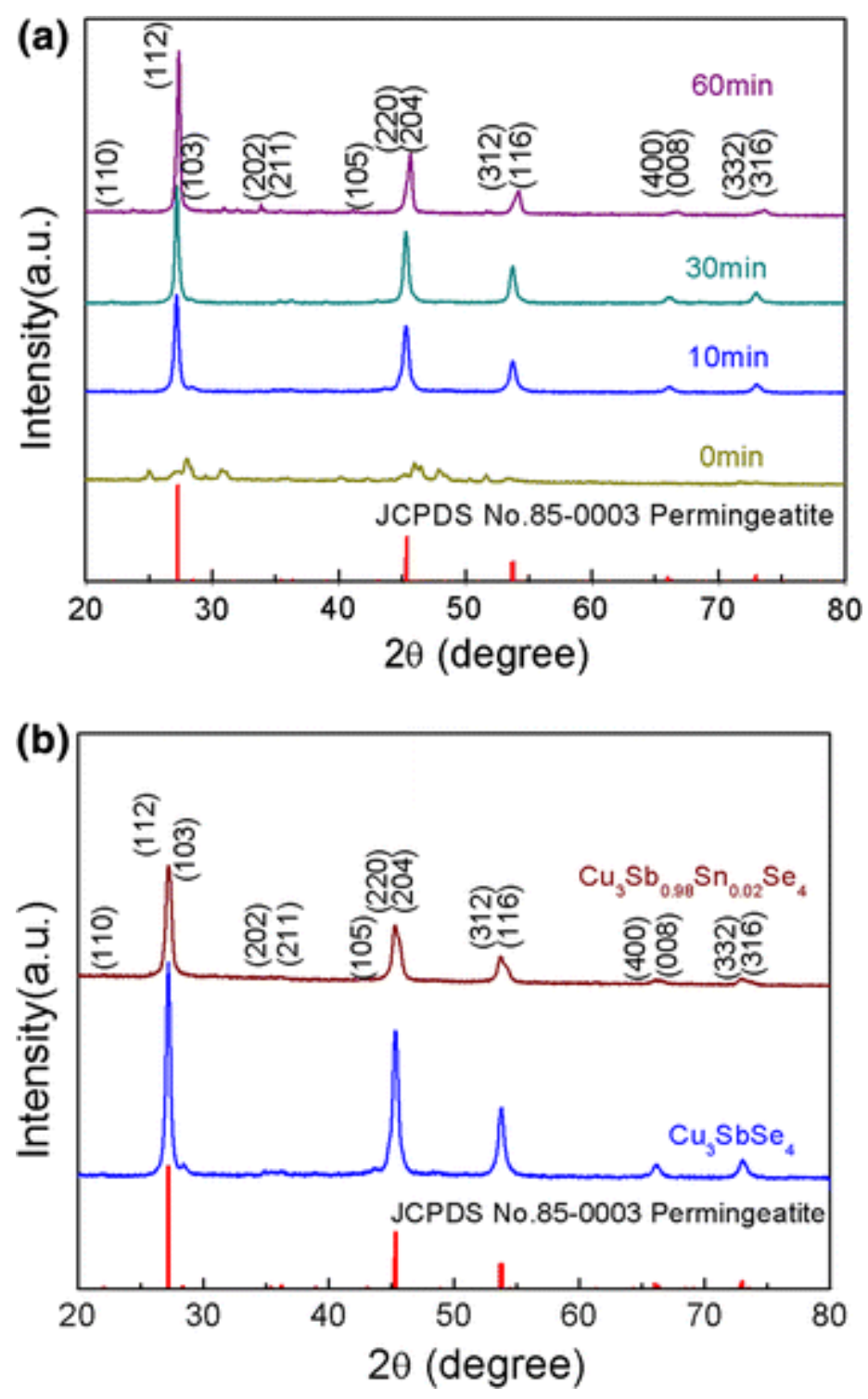

Fig.1 XRD patterns of (a) the $\mathrm{Cu}_{3} \mathrm{SbSe}_{4}$ nanoparticles which were synthesized at $180^{\circ} \mathrm{C}$ for $0 \mathrm{~min}, 10 \mathrm{~min}, 30 \mathrm{~min}$ and $60 \mathrm{~min}$, and (b) the $\mathrm{Cu}_{3} \mathrm{SbSe}_{4}$ and the $\mathrm{Cu}_{3} \mathrm{Sb}_{0.98} \mathrm{Sn}_{0.02} \mathrm{Se}_{4}$ nanoparticles which were synthesized at $180^{\circ} \mathrm{C}$ for $10 \mathrm{~min}$. 

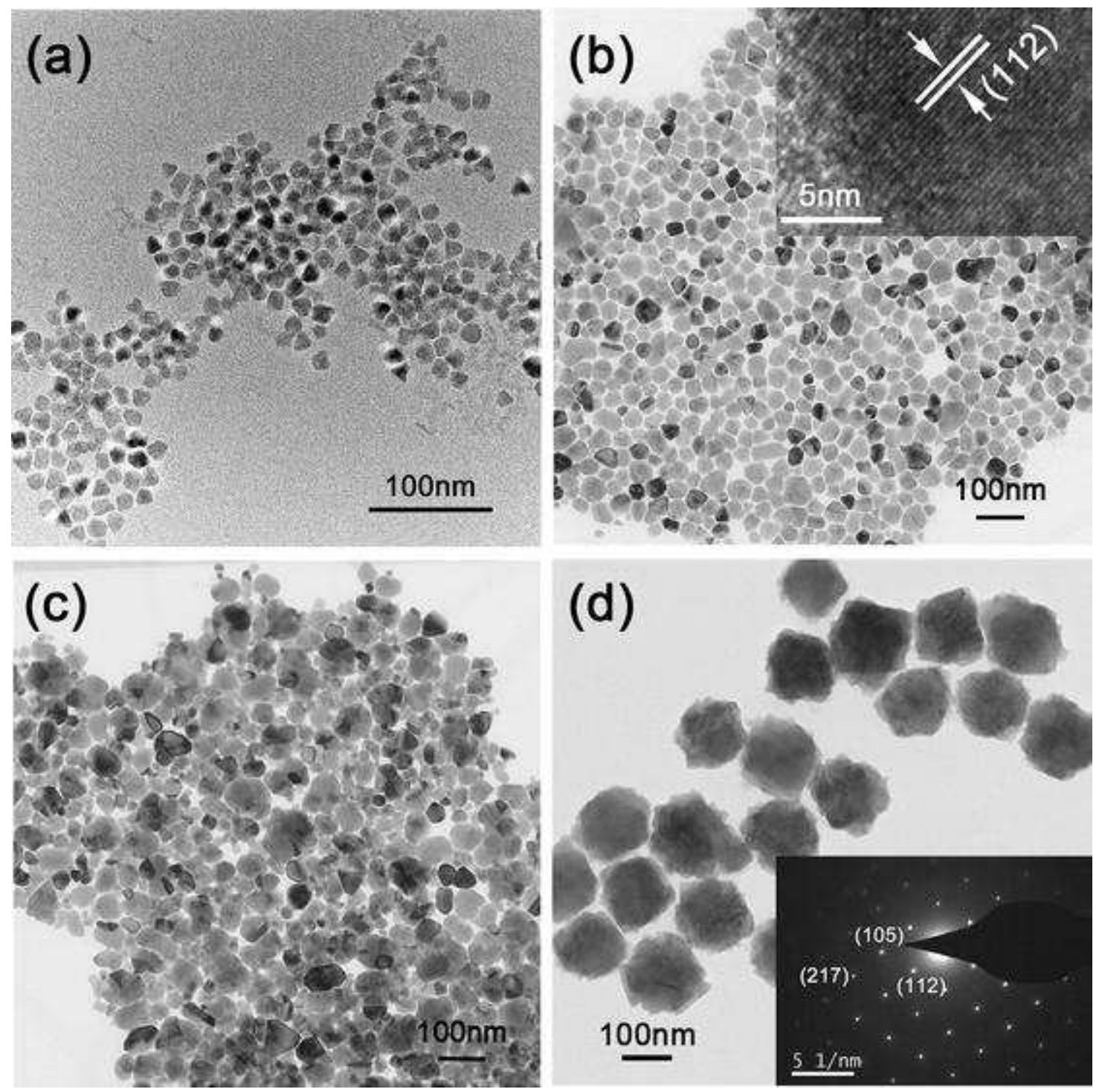

Fig.2 TEM images of the $\mathrm{Cu}_{3} \mathrm{SbSe}_{4}$ nanoparticles which were synthesized at $180^{\circ} \mathrm{C}$ for (a) 0 min, (b) $10 \mathrm{~min}$, (c) $30 \mathrm{~min}$, and (d) $60 \mathrm{~min}$. Inset: (b) HRTEM images, and (d) district electron diffraction diagrams. 

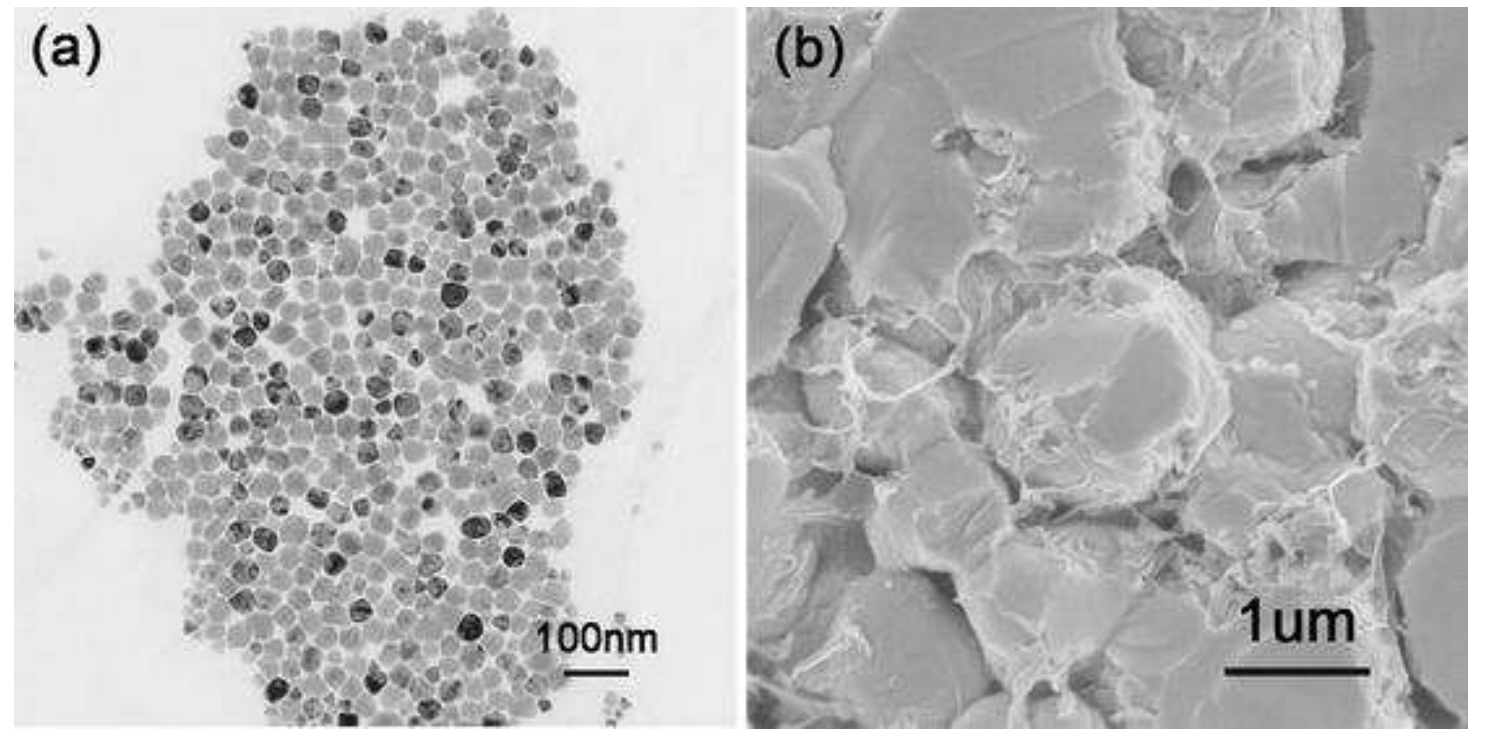

Fig.3 (a) TEM image of the $\mathrm{Cu}_{3} \mathrm{Sb}_{0.98} \mathrm{Sn}_{0.02} \mathrm{Se}_{4}$ nanoparticles which were synthesized at $180^{\circ} \mathrm{C}$ for $10 \mathrm{~min}$. (b) SEM image of bulk material which was prepared by hot-pressing sinter of the $\mathrm{Cu}_{3} \mathrm{Sb}_{0.98} \mathrm{Sn}_{0.02} \mathrm{Se}_{4}$ nanoparticles at $350^{\circ} \mathrm{C}$ for 1 hour.

(a)

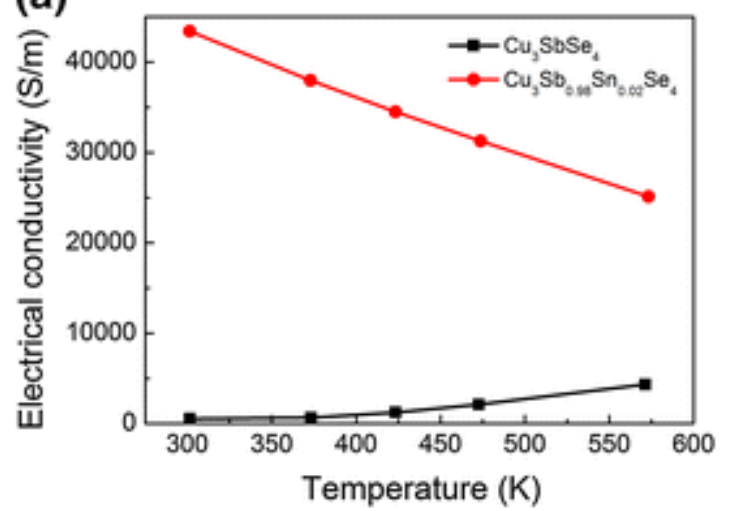

(b)

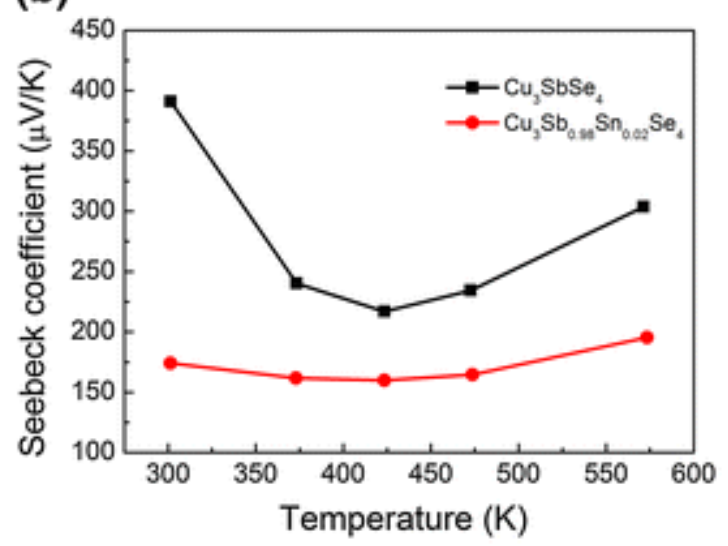

(c)

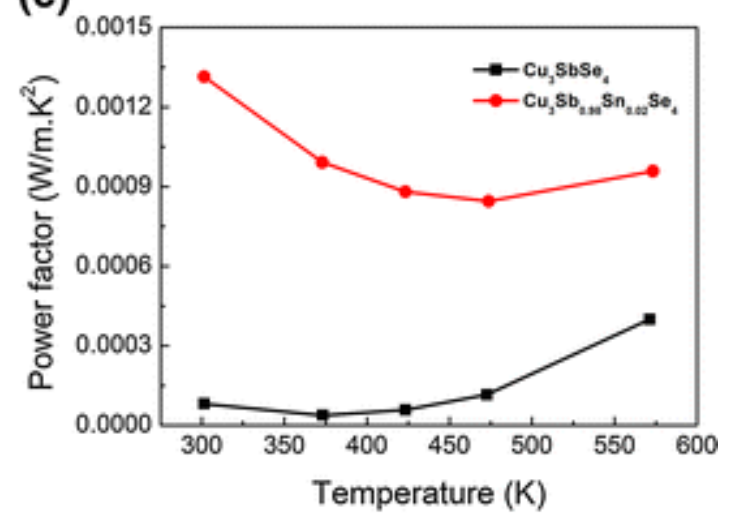

(d)

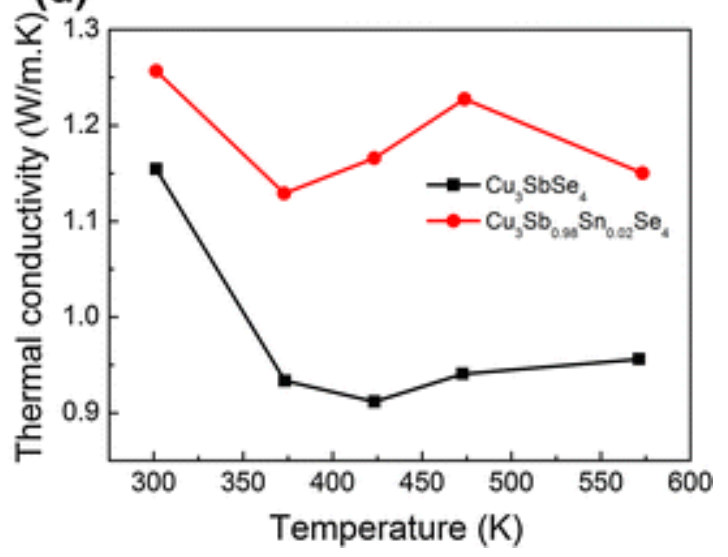


Fig.4 Dependence of thermoelectric properties on temperature for the $\mathrm{Cu}_{3} \mathrm{SbSe}_{4}$ and $\mathrm{Cu}_{3} \mathrm{Sb}_{0.98} \mathrm{Sn}_{0.02} \mathrm{Se}_{4}$ bulk materials. (a) electrical conductivity $\sigma$, (b) Seebeck coefficient $\mathrm{S}$, (c) power factor PF, and (d) thermal conductivity $\kappa$.

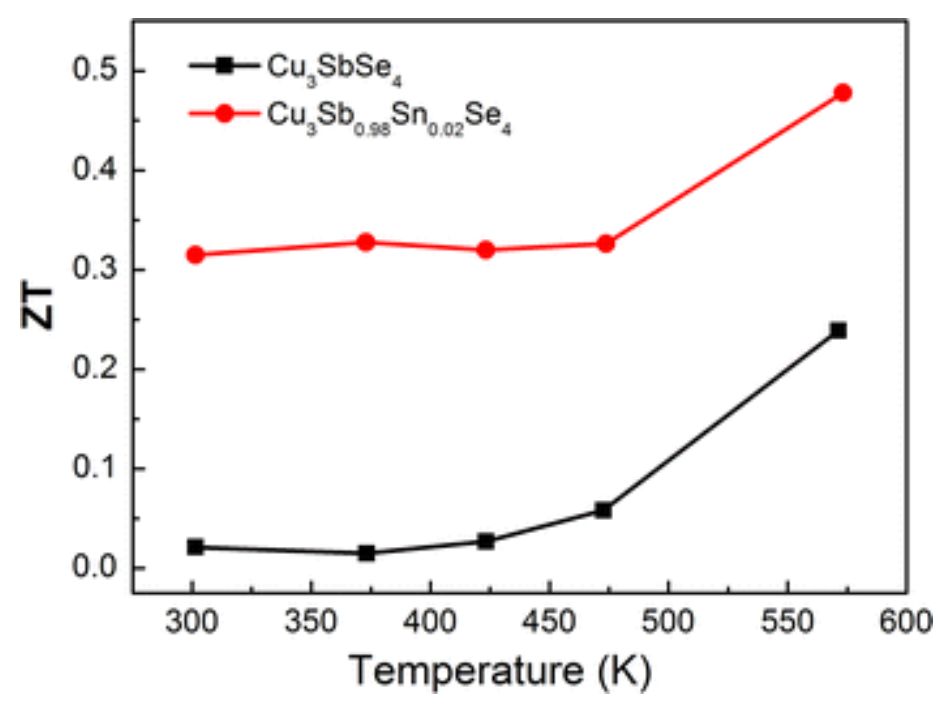

Fig.5 Dependence of the dimensionless figure of merit ZT on temperature for the $\mathrm{Cu}_{3} \mathrm{SbSe}_{4}$ and $\mathrm{Cu}_{3} \mathrm{Sb}_{0.98} \mathrm{Sn}_{0.02} \mathrm{Se}_{4}$ bulk materials. 